\title{
A Comparative Study of Water Quality Characteristics at East Java River
}

\author{
Sri Wahyuningsih ${ }^{1}$, Nadjadji Anwar ${ }^{2}$, Edijatno ${ }^{2}$, and Nieke Karnaningroem ${ }^{3}$
}

\begin{abstract}
Water is the natural resources have the function of very importance for human life and also as authorized capital in development. Water will influence by the other component. Exploiting of water to support all human life must done with wise action to management so that not result damage at water resource. As place relocation of water hence river have the selected capacities that able to change because natural activity and antropogenik. This research was conducted in nine major rivers in East Java. The objectives of this study were: 1) Identifying the characteristics and concestration range of water quality parameter, 2) Comparison the level of pollution in rivers in East Java. The results of this study indicated that the characteristic of water quality parameter of rivers in East Java were generally physical, chemical and biological. The comparison result of water quality parameter basically showed that in general the $\mathrm{pH}$ was still under threshold that had been determined, that was $\mathrm{pH}$ from 6 to 9. In general, DO concentration ranged from 0.5 $\mathrm{mg} / \mathrm{l}$ to $7 \mathrm{mg} / \mathrm{l}$, BOD concentration ranged from $3 \mathrm{mg} / \mathrm{l}$ to 11 $\mathrm{mg} / \mathrm{l}$ and the COD concentration ranged between 0.5 $\mathrm{mg} / \mathrm{liter}$ to $35 \mathrm{mg} / \mathrm{l}$.
\end{abstract}

Keywords - water quality, pH, DO, BOD, COD

\section{INTRODUCTION}

$\mathrm{R}$ iver is one of the natural water resources that must be protected from the influence of wastewater or pollutants, which means that the quality of river water must be secured from runoff pollutants originating from industrial waste, domestic waste, agricultural waste and others [8].

Disposal of industrial or non-industrial waste water, either treated or untreated, flowing into the river has the potential to cause pollution of river. This is because of the contents of each load of wastewater discharged into the river. This sort of wastewater contains physical, chemical and biological parameters that can change river water quality or affect the amount of dissolved oxygen in the river [8].

River water is said to be polluted if the degree of physical, chemical, and biological parameters in the water has exceeded the minimum threshold. This is in accordance with the provisions stated in article $1 / 11$ Life Protection Act; substances or energy or components that exist or should exist or are contaminated element are restricted in a certain resource as environmental elements. With the stipulation, what becomes the problem is that the existing waste does not exceed the predefined threshold. In fact, the waste-mixed river

${ }^{1}$ Sri Wahyuningsih is Student of Civil Engineering Doctorate Program, FTSP, Institut Teknologi Sepuluh Nopember, Surabaya, 60111, Indonesia. E-mail: sriwahyuningsih_tep@yahoo.com.

${ }^{2}$ Nadjadji Anwar and Edijatno are with Departement of Civil Engineering, FTSP, Institut Teknologi Sepuluh Nopember, Surabaya, 60111, Indonesia. E-mail: nadjadji@ce.its.ac.id, edijatno@ce.its.ac.id.

${ }^{3}$ Nieke Karnaningroem is with Departement of Environtmental Engineering, FTSP, Institut Teknologi Sepuluh Nopember, Surabaya, 60111, Indonesia. E-mail: asdir2@pps.its.ac.id. water remains in use by the public and, if used continuously, it will have an impact on health [2]. One of the efforts to reduction contamination of river water is by using water quality modelling [7 and 6]. Usage of the water quality modelling is able to improve river water quality up to $90 \%$ [9].

This research is conducted in nine major rivers in East Java, they are Solo River, Lamong River, Wonokromo, Kali Tengah River, Rejoso River, Welang River, Bedadung River, Sampean River and Kali Baru River. The parameters evaluated in this study are $\mathrm{pH}$, concentrations of Dissolved Oxygen (DO), Biological Oxygen Demand (BOD) and Chemical Oxygen Demand (COD). These parameters are the key parameters in the analysis of pollution.

The objectives of this study are: 1) to identify the characteristics of water quality parameter, 2) to compare the level of pollution in rivers in East Java and 3) to identify the concentration range of river water quality parameter in East Java.

\section{METHOD}

\section{A. Data Inventory and Identification}

Water quality data are obtained from the relevant agencies of the East Java Provincial Irrigation Department, which consisted of data of $\mathrm{pH}$, concentration of DO, BOD and COD in the rivers in East Java.

\section{B. Data Analysis}

Data analysis was compared to observe any changes in the graphical pattern or trends that occur. It is then analyzed descriptively based on the conditions of each river, it is the contribution of the load of waste that enters into the river causing the water pollution of rivers.

\section{RESULT AND DISCUSSION}

\section{A. Quality Parameters in East Java Rivers}

Characteristics of water quality parameters of rivers in East Java are generally physical, biological and chemical. The physical parameter could be indicated by the level of turbidity, the level of solubility (TSS) and (TDS), changes of water color and temperature. Biological parameters are indicated by the number of water animals, water plants and microorganisms in the water that could still be alive. Meanwhile, the chemical parameters could be indicated by the level of oxygen concentration in the water with parameter indicators of DO, BOD and COD. The concentration of DO in water world has an inverse relationship with concentrations of BOD and COD. The increasing DO concentration in river water is due to the high concentrations of $\mathrm{BOD}$ and COD. Thus, on this condition, it can be concluded that river water quality experiences degradation or even pollution. The location of the study is seen in Fig. 1.

Generally the characteristics of river water quality parameter at East Java shows the result as follows: that 
the conditions of water quality at some rivers still reside at boundary condition which have been determined. Welang river, Rejoso river and Bedadung river show good result that is pursued in the laboratory test, condition of water quality parameter is fulfilled standardly of water quality which has been determined. Bengawan Solo river, Lamong river, Wonokromo river, Kali Tengah river, Sampean river and Kali Baru river show unfavourable result that is pursued in the laboratory test, Condition of water quality for a few important parameters as water pollution indicator is exceeded the boundary conditions which determine the standard [3].

Based on land use, as shown in Table 1, it shows that land use for industrial in East Java is equal to $0.081 \%$ and for settlement is equal to $11.7 \%$ is while for the rice field of irrigation is equal to $19.9 \%$, wet ricefield of rain dependant of $10.04 \%$, plantation is equal to $18.5 \%$, farm is equal to $19.2 \%$ and also pond is equal to $2.03 \%$. Types of land use have the biggest potency in giving the waste contribution into river water then able to generate contamination of river water. Industrial activity will yield industrial disposal; the activity of resident will yield domestic waste; and agricultural activity for the rice field farm, plantation, farm and pond will yield the agriculture waste that have potency entering to the river. Based on the above descriptions, it can be analysed that in general for the East Java province the characteristics of source river water pollution are generated by the contribution from industrial disposal equal to $0.099 \%$, from domestic waste equal to $14.36 \%$ and from agriculture waste equal to $85.53 \%$. Inferential is thereby based on the map of land use in East Java, in general, the wastes have big potency entering the river and give the contribution in the case of water pollution contaminating the rivers in East Java; it is coming from agriculture waste that is equal to $85.53 \%$. Fertilization impact at the water body can increase the amount of alga so increasing amount of organic total carbon and carbon dissolve organic [10].

If evaluated from level of compound, pollution concentration entering the river and the frequency giving the contribution to contamination in river have potency to cause the contamination in river and assess very dangerously because containing assorted of chemical compound can decrease river water quality although percentage of from industrial disposal type only $0.099 \%$.

Based on land use like Table 1 shows that land use to industrial in East Java is equal to $0.081 \%$ and for settlement equal to $11.7 \%$ is while for the rice field of irrigation equal to $19.9 \%$, wet ricefield dependant to rain of $10.04 \%$, plantation equal to $18.5 \%$, farm equal to $19.2 \%$ and also pond equal to $2.03 \%$. Type of land use is having the biggest potency in giving the waste contribution into river water than able to generate contamination of water river. Industrial activity will yield industrial disposal, from activity of resident will yield the domestic waste and from agricultural activity for the rice field farm, plantation, farm and pond will yield the agriculture waste that have potency to entering to the river. Base on above description can be analysed that in general for the East Java province the characteristic of source river water pollution generated by the contribution from industrial disposal equal to $0.099 \%$, from domestic waste equal to $14.36 \%$ and from agriculture waste equal to $85.53 \%$. Inferential thereby that base on the map of land use in East Java, in general the is waste have the big potency enter in the river and give the contribution in the case water pollution contamination at the rivers in East Java is coming from agriculture waste that is equal to $85.53 \%$. Fertilization impact at the water body can increasing amount of alga so increasing amount of organic total carbon and carbon dissolve organic [10].

But if evaluated from level of compound polution concentration which enter into the river and the frequency that giving the contribution to contamination in river hence for certain that contribution of industrial disposal is the waste have potency in cause the happening of contamination in river and assessed very dangerous because containing assorted of chemical compound that able to decrease river water quality although percentage of from industrial disposal type only $0.099 \%$.

\section{B. Comparison of Contamination Level Occurred in Rivers in East Java}

a) Comparison of Degree of Acidity $(\mathrm{pH})$

$\mathrm{pH}$ is an indicator that shows the level or degree of acidity of a solution. From the analysis of $\mathrm{pH}$ data as shown on Fig. 21, it can be seen that, in general, all observed rivers in this research are still in the range of thresholds determined in accordance with PP 82 / 2001 class III, that is the $\mathrm{pH}$ value between 6 to 9 . There is no any river $\mathrm{pH}$ below 6 , which means that it is acidic or above 9 which means alkaline. It can be concluded that the contribution of waste going into rivers in East Java has a relatively normal level of acidity; that is the average $\mathrm{pH}$ value of 7.5 .

b) Comparison of concentrations of Dissolved Oxygen

(DO)

Dissolved Oxygen (DO) is the amount of concentration of oxygen that is contained in river water. Threshold of DO concentration in river water that has been determined in accordance with the Government Rule 82 Th. 2001 Class III is at least $3 \mathrm{mg} / \mathrm{l}$. In this limit, the organisms in the water can still be alive.

From the analysis of data of DO on all observed rivers as seen on Fig. 3, it can be seen that Kali Tengah, Solo River downstream, and Kali Lamong and Kali Wonokromo have DO concentrations below the specified threshold, that is below $3 \mathrm{mg} / \mathrm{l}$. Meanwhile, the Solo River upstream, and other rivers are at DO concentration above $3 \mathrm{mg} / \mathrm{l}$. This shows that rivers with concentration of DO below $3 \mathrm{mg} / \mathrm{l}$ are those on which there were many industry along the banks. Meanwhile, the rivers that had DO concentrations above $3 \mathrm{mg} / \mathrm{l}$ were those on which there were not many industries along the banks that disposed wastes into rivers such as the Bedadung River and Sampean River.

c) Comparison of Concentrations of Biological Oxygen Demand (BOD)

The amount of BOD concentration has an inverse relationship with the concentration of DO. The threshold value of BOD that has been determined in accordance with PP 82 / 2001 class III is a maximum of $6 \mathrm{mg} / \mathrm{l}$. From the results of data analysis, it could be seen in Fig. 4 that the graph of the highest BOD fluctuation of the river is on Kali Tengah, in which BOD concentration 
reaches $11 \mathrm{mg} / \mathrm{l}$ at the fifth observation points. One of the causes of this is the contribution of waste in the Kali Tengah upstream, that is the input from Brantas River.

Based on the research [11], that Brantas river water at the link between the Kertosono station and Lengkong Baru DAM Mojokerto contains organic pollutants from industrial waste, of approximately $33 \%$, and it comes from domestic waste of $67 \%$.

Rivers that have BOD concentration more than 6 mg/liter are the Bengawan Solo River downstream, Kali Tengah, and Wonokromo River and Lamong River.

d) Comparison of Concentrations of Chemical Oxygen Demand (COD)

In general, the concentration of COD contained in the water of the river in East Java still does not exceed the standard level that has been determined in accordance with PP 82 / 2001 Class III, that is a maximum of 50 $\mathrm{mg} / \mathrm{l}$, which means that the chemical oxygen demand in water in laboratory conditions ranged from 0 to $35 \mathrm{mg} / \mathrm{l}$.

In general, the characteristics of water quality parameter of rivers in East Java show the following results: the condition of water quality in some rivers is still at threshold that has been determined; furthermore, and its use is in accordance with the allocation. Welang river, Rejoso river and Bedadung river show good results based on laboratory tests; the condition of water quality parameter met predetermined quality standards. Meanwhile, Solo River, Lamong river, Wonokromo river, Kali Tengah, and Sampean River and Kali Baru do not show good results based on laboratory tests; their water quality conditions for some important parameters as indicators of contamination exceed the predetermined threshold, so that no water quality standard is not in accordance with its allocation [3].

Based on land use map designation in East Java, in general, the wastes that potentially come into the river and contributed incidence of pollution in rivers in East Java are derived from agricultural waste which is equal to $85.53 \%$. However, the concentration of pollutants that enter into the river and its frequency in contributing to the occurrence of pollution in the river, it can be ascertained that the contribution of industrial wastes are those that potentially cause the pollution in rivers and are considered very dangerous because they contain various chemicals that could degrade the water river quality.

The result is then manually analysed water quality data and then it is compared to the model use water quality modelling. The model used to running data of river water quality at the East Java is Model of HP2S (Hidrodinamik Penyebaran Polutan Di Sungai or Hydrodynamics of Pollutant Spreading at the River), with constrain as follows:

1) Model illustration use the model HP2S and the visualisation use the Mathlab R12 program.

2) Parameter used is parameter non-conservative ( is very influenced by dissolve oxygen in water), that is BOD, COD, PO4 and DO.

3) In application of model HP2S, the natural influence like wind, evaporation, sea-water ebb, lateral river, rain and ground water run off are disregarded.

4) Spreading pattern of pollutant that evaluated is at the river bank with diametrical river condition without run off, laminar stream river and crudity of channel base and also wall disregarded or assumed slippery.
All data come from secundary data, either from on duty irrigating, Balai Pengelolaan Sumberdaya Air Wilayah Sungai (BPSAWS) or result of former research.

Running of HP2S modell is based on the algorithm programm which have been made. The data enter atrunning the model HP2S is:

1) $P$ = river length $(\mathrm{m})$

2) $\mathrm{L}=$ wide $[\mathrm{of}]$ river $(\mathrm{m})$

3) $d=$ deepness of river $(\mathrm{m})$

4) $\mathrm{u}_{\mathrm{x} 0}=$ speed of river to axis of the abscis $(\mathrm{m} / \mathrm{det})$

5) $\mathrm{v}_{\mathrm{y} 0}=$ speed of river to axis of the ordinate $(\mathrm{m} / \mathrm{det})$

6) $\mathrm{c}_{\mathrm{o} 0}=$ parameter concentration early river $(\mathrm{mg} / \mathrm{l})$

7) $\mathrm{q}_{0}=$ discharge $(\mathrm{m} 3 / \mathrm{det})$

In the running process, if data input from unstable parameter and river data are not consistent and not convergent, they will emerge the program appearance error, so that needed checking to data input and river parameter entered.

Running result is obtained by visualizing from pattern change of river water quality and spreading pattern of parameter concentration, and visualizing this visible and printed pass the Matlab R12 program.

One of the results of running the program can be seen as the following figure. Image of change patterns of flow speed in Bengawan Solo river (KSO-2a) can be seen in Fig. 6 and 7.

From Fig. 6 and 7, it can be seen that the river flow velocity decreases along the axis $x$. Suppose that the starting point velocity is at a distance of $0 \mathrm{~m}$ from the river length at the observed point with initial flow velocity of $0.5 \mathrm{~m} / \mathrm{sec}$, then at a distance of about $5 \mathrm{~m}$, the speed will be reduced to $0.2 \mathrm{~m} / \mathrm{sec}$, until at a distance of about $12 \mathrm{~m}$ the flow velocity is close to zero. This can happen because it is assumed that there is no flow of runoff from creeks, irrigation and other runoff sources such as industry and domestic.

For the width of the river (axis y), the flow velocity also decreased in line with the increasing width of the river, as shown on Fig. 8 and 9. On the banks of the river, the flow velocity to width of river is assumed 0.1 $\mathrm{m} / \mathrm{sec}$. The closer to the centre, the more it decreases, until at a distance of about $10 \mathrm{~m}$ from the edge of the river flow velocity closely to 0 (zero).

Thus, the speed of the spread of BOD, COD, $\mathrm{PO}_{4}$ and DO in Bengawan Solo River on KSO-2 segment decreased along the river up to a distance of $12 \mathrm{~m}$ from the starting point of observation and $10 \mathrm{~m}$ from the riverbank.

Image of patterns of changes in the parameter concentrations of BOD, COD, $\mathrm{PO}_{4}$ and DO in Solo River (KSO-2a) is shown as follows:

1) BOD

From Fig. 10 and 11, it can be seen that the BOD concentration decreases along the axis $\mathrm{x}$ and axis $\mathrm{y}$. At first, the BOD concentration was $7.0 \mathrm{mg} / \mathrm{l}$ at the river bank. Because of the speed of flow, BOD concentration is then spread towards the length and wide of river. Based on colour change in Fig. 10 and 11, it is seen that the distribution of the furthest visible BOD concentrations nearly $0 \mathrm{mg} / \mathrm{l}$ is at a distance of approximately $13 \mathrm{~m}$ along the river and $15 \mathrm{~m}$ from the river bank.

2) COD

From Fig. 12 and 13, it can be seen that COD concentration decreases along the axis $\mathrm{x}$ and axis $\mathrm{y}$. At 
first, the concentration of COD is $15.8 \mathrm{mg} / \mathrm{lt}$ the river bank. Because of the speed flow, concentration of COD is then spread for wards length and wide of river. Based on colour changes displayed in Fig. 12 and 13, it is seen that the COD farthest distribution at concentration close to $0 \mathrm{mg} / \mathrm{l}$ is at a distance of approximately $13 \mathrm{~m}$ along the river and $15 \mathrm{~m}$ from the river bank.

3) $\mathrm{PO}_{4}$

From Fig. 14 and 15, it can be seen that the concentration of $\mathrm{PO}_{4}$ decreases along the axis $\mathrm{x}$ and axis $\mathrm{y}$. At first, the $\mathrm{PO}_{4}$ concentration is $0.0361 \mathrm{mg} / \mathrm{l}$ at the river bank. Because of the flow velocity, the concentration of PO4 is then spread towards the length and width of river. Based on colour change in Fig. 14 and 15, the furthest $\mathrm{PO}_{4}$ distribution with a concentration close to $0 \mathrm{mg} / \mathrm{l}$ is at the distance of approximately $13 \mathrm{~m}$ along the river and $15 \mathrm{~m}$ from the riverbank.

4) DO

From Fig. 16 and 17, it can be seen that the DO concentration decreases along the axis $\mathrm{x}$ and axis $\mathrm{y}$. At first, the DO concentration is $1.06 \mathrm{mg} / \mathrm{l}$ at the river bank. Because of the flow velocity, the concentration of DO is then spread towards the length and width of river. Based on color change in Fig. 16 and 17, it is seen that the farthest DO range concentration nearly $0 \mathrm{mg} / \mathrm{l}$ is at a distance of approximately $13 \mathrm{~m}$ along the river and $15 \mathrm{~m}$ from the riverbank.

Based on the results of the whole running of the program, it can be concluded that the patterns of the spread of pollutants in the rivers in East Java are relatively nearly the same on the river water toward the whole observed parameters in this research. The concentrations of BOD, DO, COD, PO4 are at spread average with a radius of diameter of the spread between 10 to 15 meters. At this point, pollutants will spread and the concentration will decrease close to zero, which means that the river water can make self-purification at this diameter. However, what happened on the field is prior to achieving the distance of 10 or 15 meters, there have been the other points of disposal. This causes the process of self-purification can not run properly, so that the rivers get additional pollutant loads and cause the river water pollution.

\section{CONCLUSION}

Based on the analysis and discussion above, it can be concluded that:

1) The comparison of water quality parameters of the rivers in East Java basically shows that, in general, the $\mathrm{pH}$ is still at threshold that has been determined, that is $\mathrm{pH}$ between 6 to 9. Comparison of leave for back DO and BOD concentrations shows that the rivers on which there are relatively not many industries along the banks still have a high DO concentration more than $3 \mathrm{mg} / \mathrm{l}$ and a relatively low BOD concentration below the threshold, that is in below $6 \mathrm{mg} / \mathrm{l}$. This is in contrast with rivers along the banks on which there are many industries. And in general all the observed rivers have COD concentration below the predetermined threshold of maximum $60 \mathrm{mg} / \mathrm{l}$.

2) In general, it is shown that the concentrations of water quality parameters of rivers in East Java for the $\mathrm{pH}$ range from 6 to 9 , DO concentrations range from $0.5 \mathrm{mg} / \mathrm{l}$ to $7 \mathrm{mg} / \mathrm{l}$, BOD concentrations range from 3 $\mathrm{mg} / \mathrm{l}$ to $11 \mathrm{mg} / \mathrm{l}$ and the COD concentrations range between $0.5 \mathrm{mg} / \mathrm{l}$ to $35 \mathrm{mg} / \mathrm{l}$.

3) Based on the results of the whole running of the program, it can be concluded that the patterns of the spread of pollutants in rivers in East Java are relatively nearly the same as the river water to the whole observed parameters in this research, that is the concentrations of BOD, DO, COD, Posphat with ave-rage spread of radius of diameter of the spread between 10 to 15 meters. At this point, pollutants will spread and concentration of pollutants will decrease close to zero.

\section{REFERENCES}

[1] Anonim, -, "Landscape in East Java Province", Water Resource Development Research Centre of Jember University.

[2] Anonim, 2000, http://www.humanrightsindonesia.org/app_att/laporan /1553871218, pdf.

[3] Anonim, 2003, "Pedoman penetapan daya tampung beban pencemaran air pada sumber air", Keputusan Menteri Lingkungan Hidup Nomor 110 Tahun 2003.

[4] Anonim, 2008a, "Water quality data at east java rivers", Watering Departement of East Java Province.

[5] Anonim, 2008b, "Map of east java rivers", Water resource development research centre of Jember University.

[6] G.A. Best, Bogacka dan E. Niemirycz, 1997, "International river water quality pollution and restoration", E\& FN SPON, London

[7] A. James, 1987, "An introduction to water quality modelling", John Wiley and Sons, Chichester.

[8] N. Karnaningroem, 2006, "Model hidrodinamika penyebaran polutan di sungai", Disertasi Program Pascasarjana Program Studi Teknik Sipil ITS Surabaya.

[9] Jin-Ho Kim, et. al.., 2003, "Estimation of pollutant load and basin management of kyung an rivers Korea", Diffuse Pollutant Conference, Dublin.

[10] Lee, Anne Jones and G. Fred Lee, 2002, "Strormwater runoff water quality science/engineering newsletter devoted to urban/rural stormwater runoff water quality management issues, physical and biogeochemicall peocesses in Antarctic lakes", Antarctic research series, Vol. 5 No. 1. G.Fred Lee and Associates, El Maciro California.

[11] Sri Wahyuningsih, 2001, "Studi tentang tingkat pencemaran Kali Brantas oleh limbah kota dengan menggunakan model duflow (ruas Kertosono- Mojokerto)", Thesis Program Pasca Sarjana Program Studi Teknik Sipil Bidang Keahlian Manajemen Sumber Daya Air Institut Teknologi Sepuluh Nopember Surabaya. 


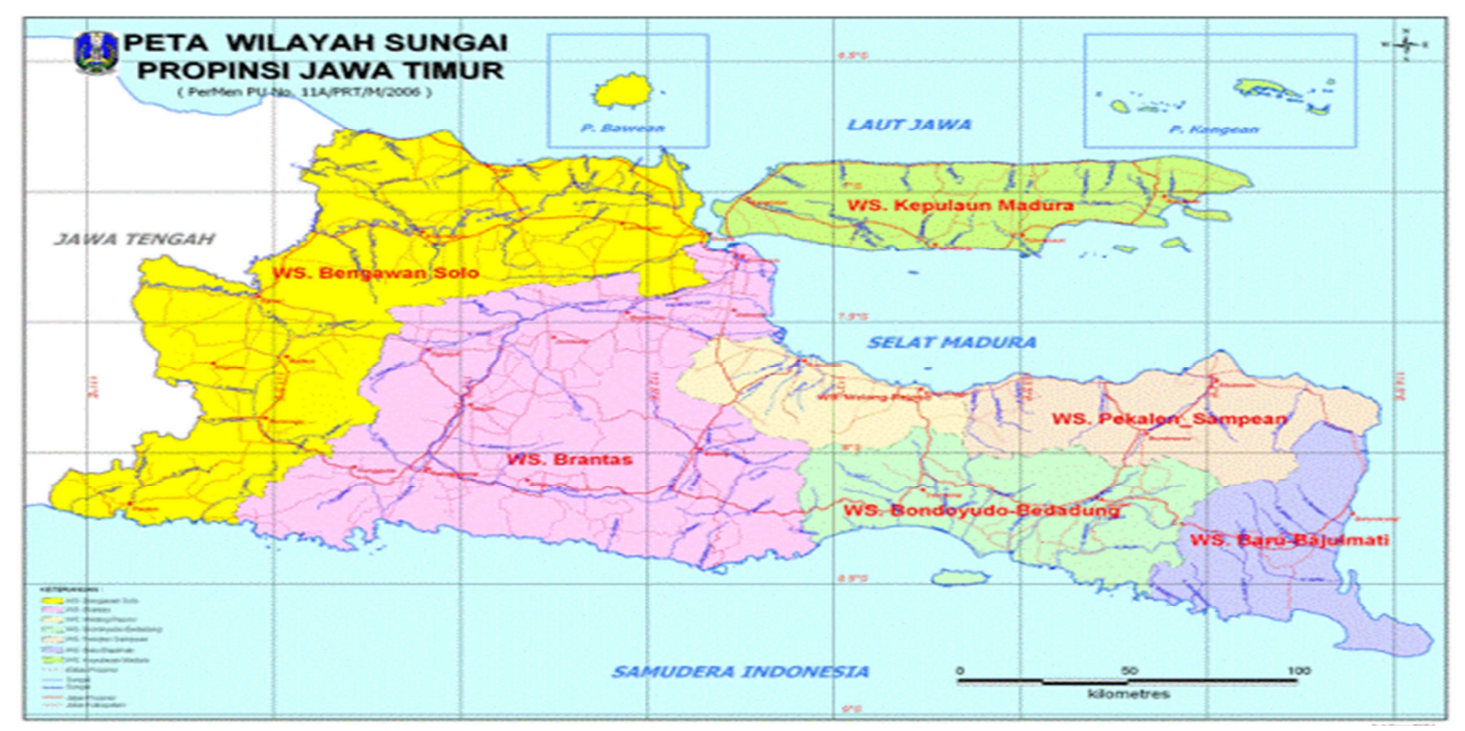

Fig. 1. Map of rivers at East Java [5]

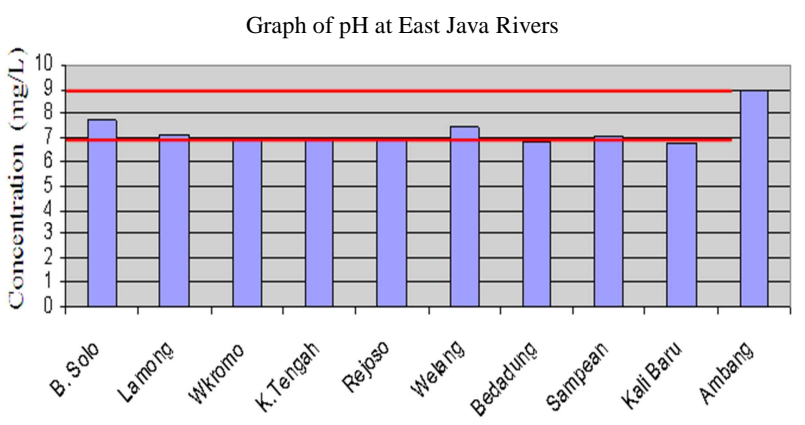

Fig. 2. Comparative graph of $\mathrm{pH}$ of rivers in East Java [4]

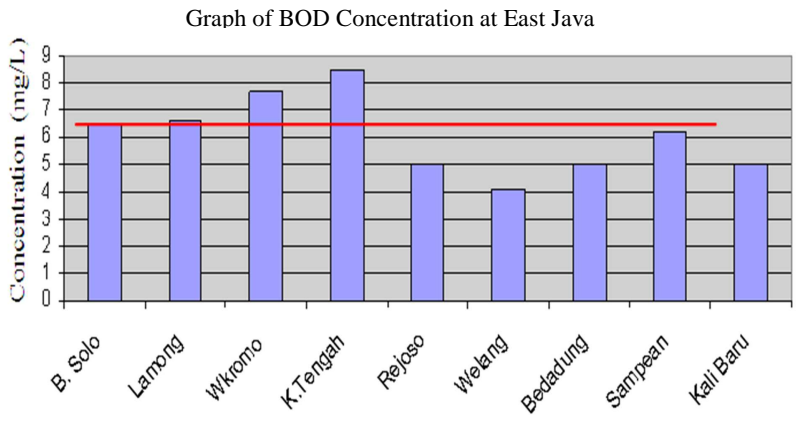

Fig. 4. Comparative graph on concentration of Biological Oxygen Demand (BOD) rivers in East Java [4]

velocity of stream laminar to axis of the abscis

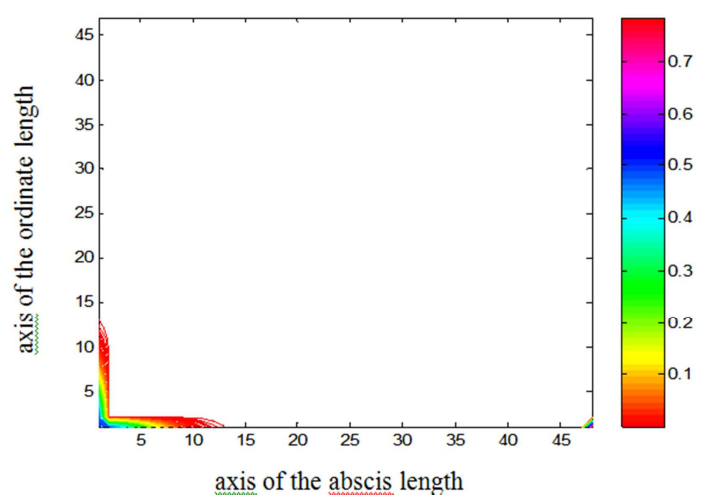

Fig. 6. Graph of changes in flow velocityof KSO-2a against length of river (indicated by color change) [4]

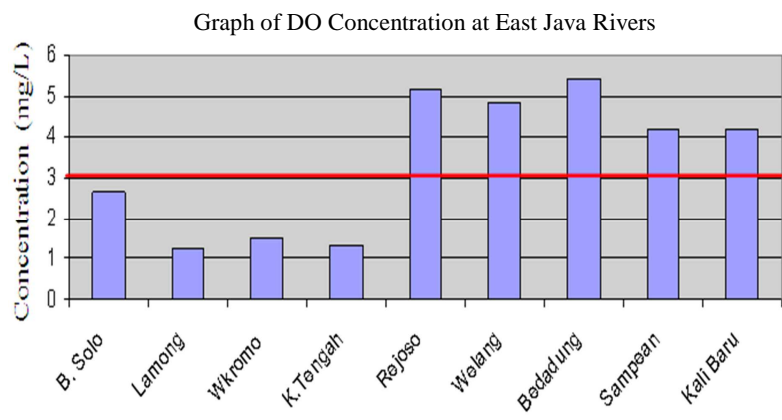

Fig. 3. Graph comparison of Dissolved Oxygen (DO) concentration of rivers in East Java [4]

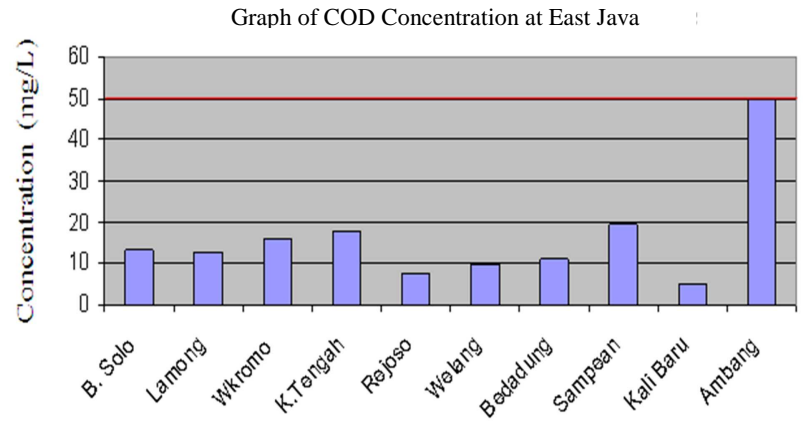

Fig. 5. Graph of comparison of Chemical Oxygen Demand (COD) Concentration of rivers in East Java [4]

Velocity of stream laminar to axis of the abscis

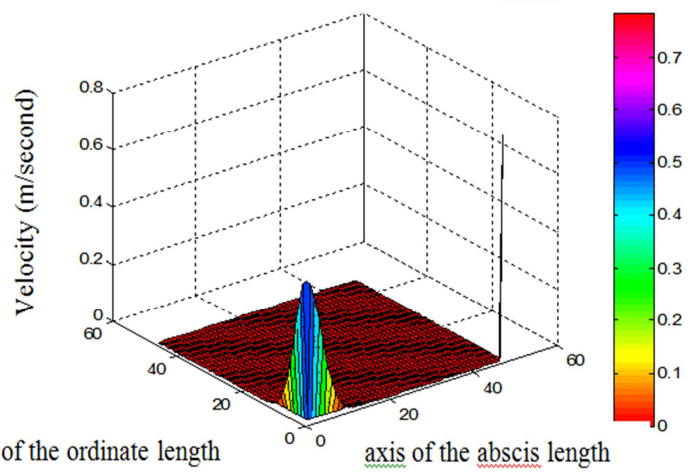

Fig. 7. Change of flow velocity in the KSO-2a against the length of river (indicated by color change) [4] 
velocity of stream polutan to axis of the ordinate

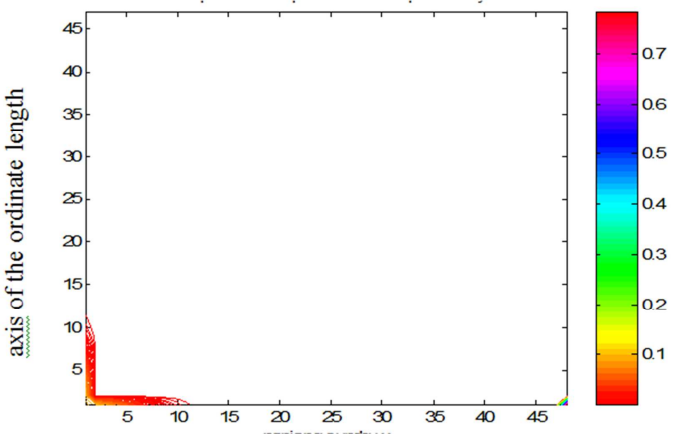

axis of the abscis length

Fig. 8. Graphic of changes in flow velocity of KSO-2a on river width (indicated by color change) [4]

concentration every set of time and distance

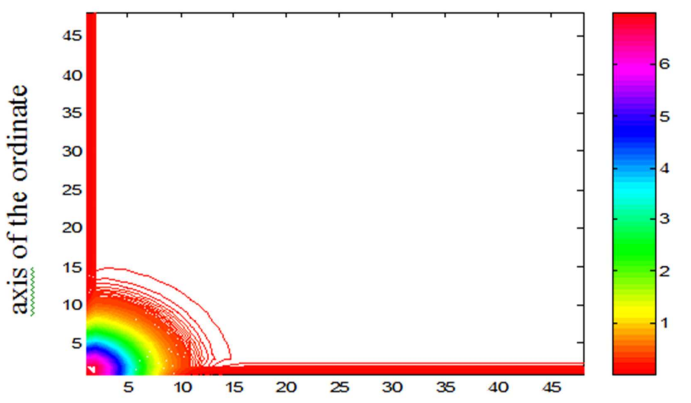

axis of the abscis length

Fig. 10. Graphic of concentration value of BOD in KSO-2a (indicated by color change) per unit of time and distance [4]

concentration every set of time and distance

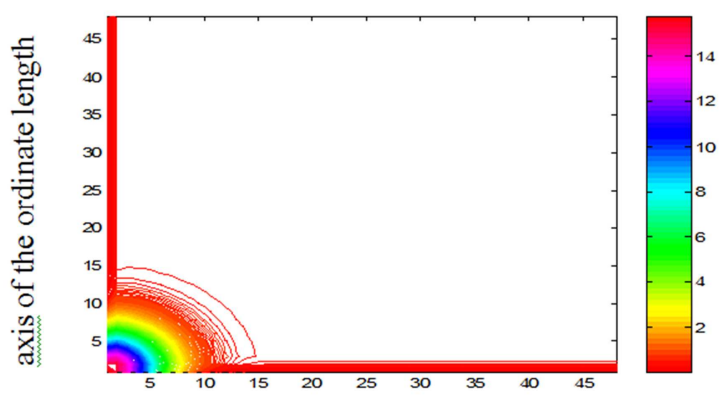

axis of the abscis length

Fig. 12. Graph of concentration value change of COD in KSO-2a (indicated by color change) per unit of time and distance [4]

concentration every set of time and distance

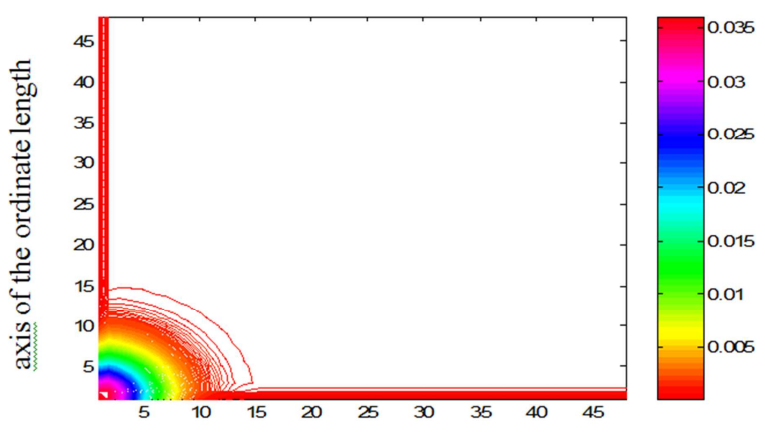

axis of the abscis length

Fig. 14. Graph of value change

of PO4 Concentration in KSO-2a (indicated by color change) per unit of time and distance [4] velocity of stream laminer at diametrical river

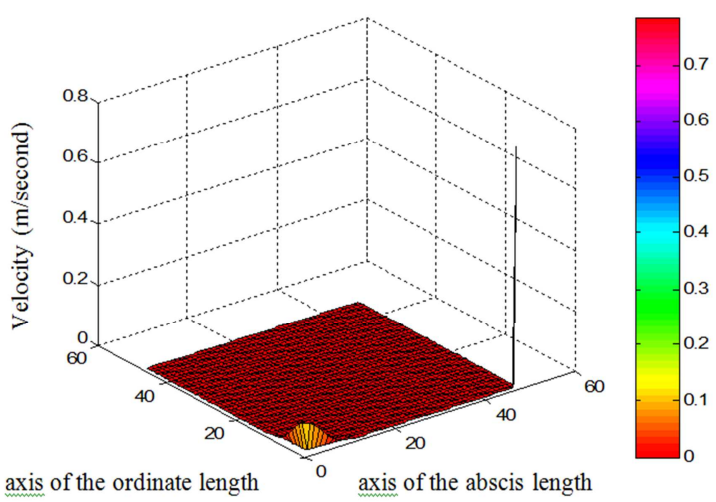

Fig. 9. Changes in flow velocity in the KSO-2a against the river lentgh (indicated by color change) [4]

concentration every set of time and distance

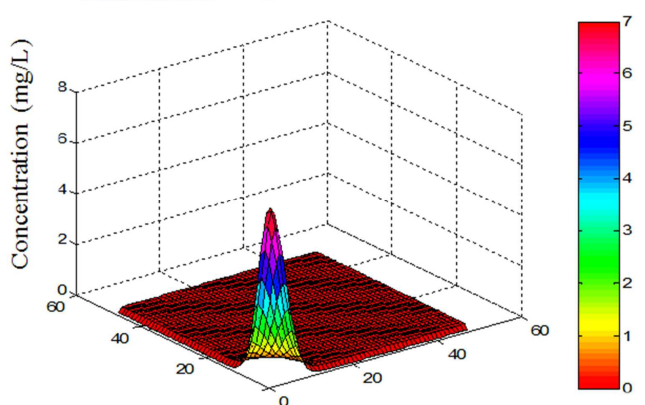

axis of the ordinate length

axis of the abscis length

Fig. 11. Changes in concentrations value of BOD at KSO-2a (indicated by color change) per unit of time and distance [4]

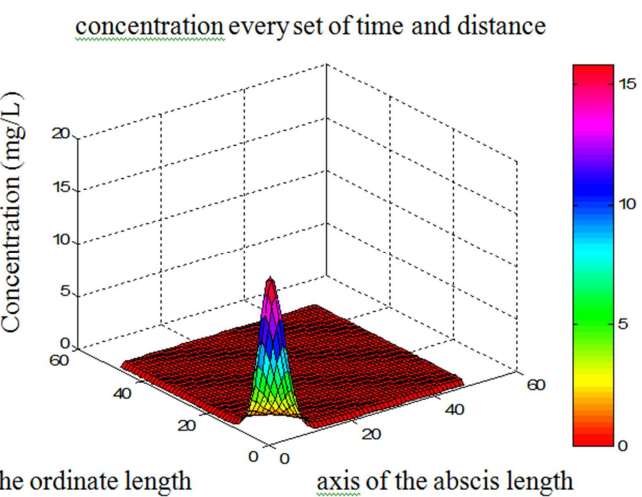

axis of the ordinate length

axis of the abscis length

Fig. 13. Changes in value of COD concentration in the KSO-2a (indicated by color change) per unit of time and distance [4]

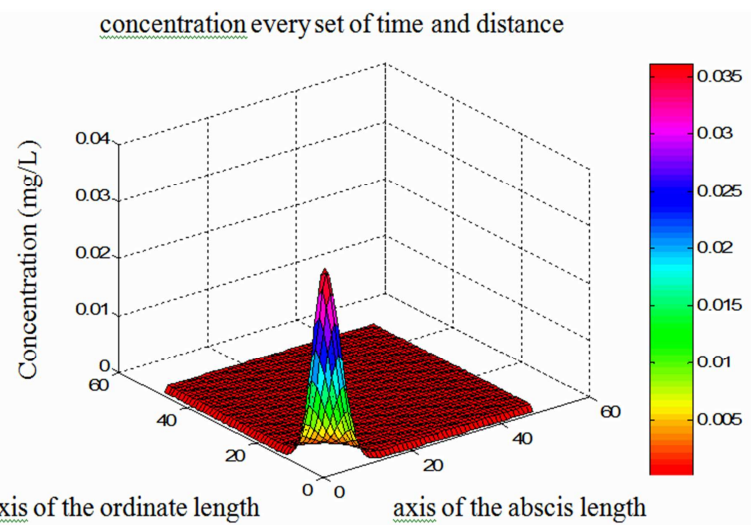

Fig. 15. Changes in PO4 concentration value KSO-2a (indicated by color change) each unit of time and distance [4] 
stream concentration every set of time and distance

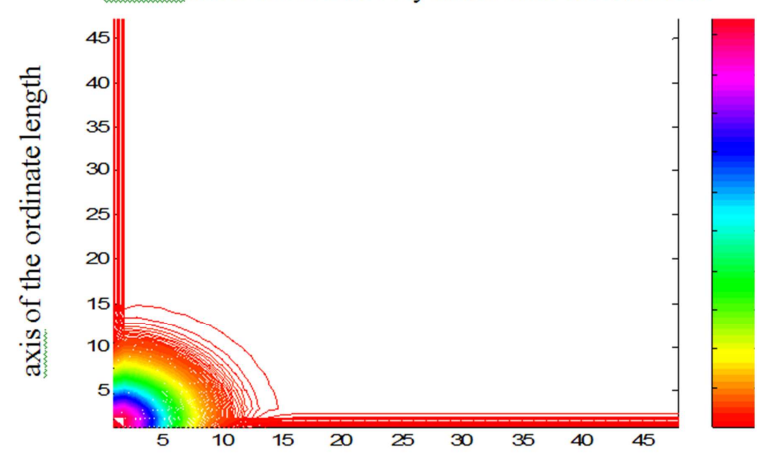

axis of the abscis length

Fig. 16. Graph of value change of

DO Concentration in the KSO-2a (indicated by color change) per unit of time and distance [4] stream concentration every set of time and distance

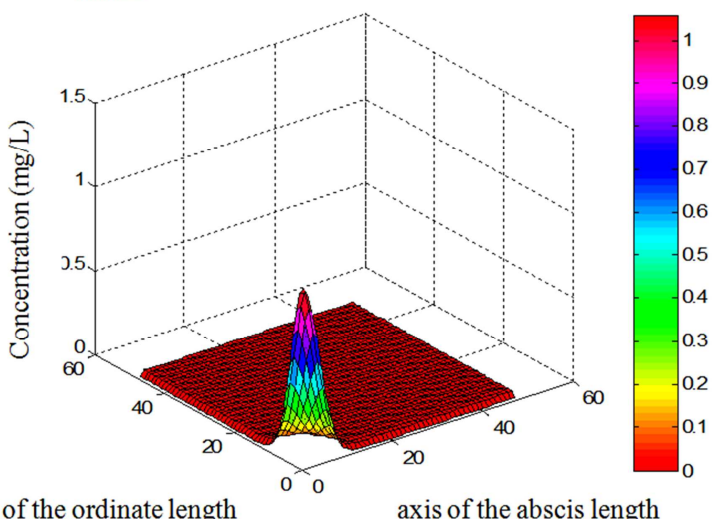

Fig. 17. Change in DO concentration value

of KSO-2a (indicated by color change) each unit of time and distance [4]

TABLE 1.

LANDSCAPE IN EAST JAVA PROVINCE [1]

\begin{tabular}{llll}
\hline No & Landscape & Wide $(\mathrm{Ha})$ & Wide $(\%)$ \\
\hline 1. & airport/port & 301.468 & 0.00064 \\
2. & lake/ barrage & 9495.582 & 0.20000 \\
3. & pond & 95671.084 & 2.03000 \\
4. & forest & 392174.084 & 8.36000 \\
5. & plantation & 867901.045 & 18.5000 \\
6. & farm & 902463.229 & 19.2000 \\
7. & fabrication/building & 3828.535 & 0.08100 \\
8. & sand & 9484.492 & 0.20000 \\
9. & settlement & 548942.218 & 11.70000 \\
10. & salting & 10083.626 & 0.22000 \\
11. & salting & 362.145 & 0.00780 \\
12. & bog/bog forest & 12577.143 & 0.26900 \\
13. & irigation rice field & 935546.118 & 19.90000 \\
14. & rice field cistern of rain & 470730.588 & 10.04000 \\
15. & coppice & 375650.437 & 8.00900 \\
16. & river & 7098.264 & 0.16000 \\
17. & wastelend & 48129.066 & 1.02700 \\
\hline
\end{tabular}

TABLE 2.

VALUe OF River WATER POLlution PARAMETER [4]

\begin{tabular}{llllll}
\multicolumn{5}{c}{ VALUE OF RIVER W } \\
\hline No. & $\begin{array}{l}\text { Name of } \\
\text { River }\end{array}$ & $\mathrm{pH}$ & $\begin{array}{l}\text { DO } \\
(\mathrm{mg} / \mathrm{l})\end{array}$ & $\begin{array}{l}\text { BOD } \\
(\mathrm{mg} / \mathrm{l})\end{array}$ & $\begin{array}{l}\text { COD } \\
(\mathrm{mg} / \mathrm{l})\end{array}$ \\
\hline 1. & Bengawan Solo & 7.8 & 2.7 & 6.5 & 14 \\
2. & Lamong & 7.0 & 1.2 & 6.7 & 12 \\
3. & Wonokromo & 6.8 & 1.5 & 7.8 & 16 \\
4. & Kali Tengah & 7.0 & 1.3 & 8.2 & 18 \\
5. & Rejoso & 7.0 & 5.1 & 5.0 & 8 \\
6. & Welang & 7.4 & 4.9 & 4.1 & 10 \\
7. & Bedadung & 6.9 & 5.4 & 5.0 & 11 \\
8. & Sampean & 7.0 & 4.1 & 6.1 & 20 \\
9. & Kali Baru & 6.7 & 4.1 & 5.0 & 4 \\
\hline
\end{tabular}


